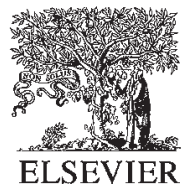

European Economic Review 45 (2001) 405-423

EUROPEAN

ECONOMIC REVIEW

www.elsevier.com/locate/econbase

\title{
Election goals and income redistribution: Recent evidence from Albania
}

\author{
Anne Case* \\ Department of Economics and the Woodrow Wilson School, Princeton University, \\ 217 Bendheim Hall, Princeton, NJ 08544, USA
}

Received 1 June 1998; accepted 1 April 2000

\begin{abstract}
This paper examines the impact of political competition on block grants from federal to sub-federal levels of government. We model the extent and direction of income redistribution as determined proximately by the political agendas of central decision makers and, at a deeper level, by the institutions within which they find themselves operating. We contrast two political objective functions that yield different empirical predictions of the ways in which politics should affect fiscal policy. Lessons learned here may prove important in understanding limits on the types of redistribution possible via block grants, given the institutional framework, in both developing and developed countries. (C) 2001 Elsevier Science B.V. All rights reserved.
\end{abstract}

JEL classification: $\mathrm{H} 1 ; \mathrm{H} 7 ; \mathrm{O} 1$

Keywords: Political objectives; Block grants; Albania

\section{Introduction}

This paper examines the impact of political competition on block grants from federal to sub-federal levels of government. We model the extent and direction of income redistribution as determined proximately by the political agendas of

*Tel.: 1-609-258-2177; fax: 1-609-258-5974.

E-mail address: accase@princeton.edu (A. Case).

0014-2921/01/\$ - see front matter (C) 2001 Elsevier Science B.V. All rights reserved. PII: S $0014-2921(00) 00078-7$ 

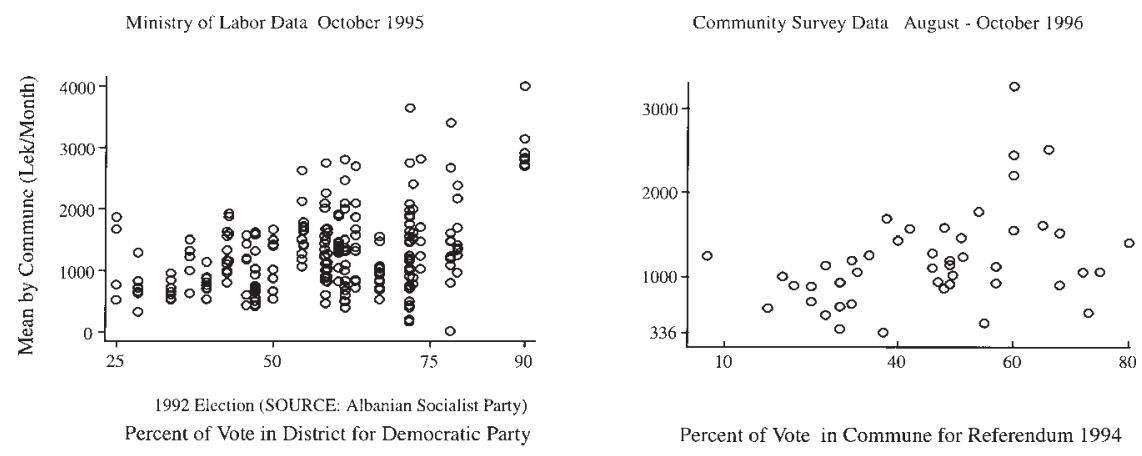

Fig. 1. Social assistance per family and the commune's votes for the Democratic party.

central decision makers and, at a deeper level, by the institutions within which they find themselves operating. We contrast two political objective functions that give way to different empirical predictions of the ways in which politics should affect fiscal policy. Lessons learned here may prove important in understanding the objective functions of decision makers, and the limits on the types of redistribution possible via block grants, given institutional frameworks in both developing and developed countries.

We take as a concrete example the extent to which political forces in Albania affect social assistance block grants from the central government to the local governments (communes). Fig. 1 presents strong prima facie evidence that politics play a role in income redistribution within the country. The first panel in Fig. 1 plots the amount of social assistance received per family in each commune in October 1995 against the percentage of the commune's district that voted with the majority (Democratic) party in local elections held in 1992. The correlation between these two variables is quite high $(0.40)$ and suggests that politics may help to determine allocations. ${ }^{1}$ The second panel in Fig. 1 is drawn from survey data collected at the commune level in the fall of 1996, and plots social assistance per family in the middle of 1996 against the percent of the commune that voted for the referendum on the constitution (favored by the Democratic party) in 1994. We see the same pattern here: communes that voted with the Democratic party received a higher level of assistance in a later period.

\footnotetext{
${ }^{1}$ In a regression controlling for heteroskedasticity with district-specific clustering, the coefficient on the percent voting for the Democratic party has a $t$-statistic of 3.0 (244 communes). Results for Fig. 1 are similar if the total amount of social assistance received by the commune (rather than that per family) in 1994, 1995, or 1996 is plotted against the 1992 election results or plotted against the fraction of the commune's district that voted for the referendum on the constitution (favored by the Democratic party) in 1994.
} 
In what follows, we explain why we would expect such allocations, given the political equilibrium in Albania.

In doing this, we provide empirical evidence relevant to three literatures. We present direct evidence on the objectives of decision makers distributing 'pork'; we highlight the impact politics can have on decentralized programs; and we draw on what has been learned in the New Deal spending literature in the United States, which is especially important in testing the robustness of our results.

\subsection{Pork-barrel politics}

Many recent papers have modeled the promises made by parties in a two-party system about the distribution (or redistribution) of income. In this literature, it is generally assumed that voters care about their own consumption and about which party is elected to office. Voters hold ideological opinions about the parties, based possibly on their historical interaction with the parties. Models by Cox and McCubbins (1986), Lindbeck and Weibull (1987), and Dixit and Londregan $(1995,1996,1998)$ are all of this form.

The promises made on income distribution depend upon the parties' objective functions and, here, papers in the literature take different turns. Dixit and Londregan $(1995,1996,1998)$ assume that each party tries to maximize its vote share or vote total. They argue that parties care about their margin of victory or about having a strong minority presence, should they not win a majority of seats.

Cox and McCubbins also develop a model in which candidates make decisions in order to maximize the number of votes received. However, they argue that risk averse candidates will over-invest in their closest supporters, relative to more risk acceptant candidates, who will more aggressively pursue 'swing' voters (those least ideologically bound to either party).

Lindbeck and Weibull contrast two possible political objectives when dividing block grant funding: maximizing the number of votes a party obtains, and maximizing the probability of winning a majority of seats. If the decision maker's objective is to maximize the number of votes obtained - as in some parliamentary elections - more funds should be allocated where races are tight. On the other hand, if the decision maker's objective is to maximize the probability of winning a majority of seats in the legislature - as is needed to form an executive in some systems - weight should also be given to those districts thought to be 'pivotal' (those without whom it would be hardest for the party to win a majority). Parties maximizing the probability of winning a majority of seats look like risk averse parties: both will put more resources in 'safe' districts (those in which the party has greater support). In a closely related paper on campaign spending, Snyder (1989) finds a party's level and allocation of campaign spending will vary, depending upon whether a party is attempting to 
maximize the number of seats won or attempting to maximize the probability of winning a majority of seats. In the latter, a party will spend more on its 'safe' races, when it has an overall advantage, because its 'safe' districts are more likely to be pivotal.

This paper tests which, if either, of these objective functions appears to be at work in the allocation of social assistance funding in Albania during the Berisha administration. Consistent with a model in which Berisha was attempting to maximize the probability of his own reelection by winning a majority of seats in the legislature, we find that not only was more assistance allocated to swing communes, but also to communes that might be pivotal. We take this as evidence that politics matter in the distribution of block grants and that, in the Albanian case, the relevant decision maker may have been a president who wanted to maximize the odds of his own reelection.

\subsection{Decentralization}

Our results also speak to the current debate on decentralization of government programs in developing countries. In some circles, decentralization is currently being touted as a mechanism capable of increasing the use of local information, of enhancing government accountability, and of limiting leakage from social programs (see Prud'homme (1995) and McLure (1995) for discussion on these issues). Such gains must be weighed against losses caused by politicians using their discretion to influence the allocation of block grants. This does not merit discussion in much of the literature on decentralization - see, for example, Litvack et al. (1998) - although the results presented here suggest that the political effects may be large.

\subsection{New deal spending}

This work is also closely related to research on fiscal federalism in the United States. There has been much written on federal government subsidization of state and local governments during the Great Depression in the United States under Roosevelt, and the extent to which federal support was politically motivated. Careful reinvestigation of New Deal spending results by Wallis (1998) highlights the sensitivity of results in this literature to empirical specification. In particular, the positive and significant correlation between New Deal spending per capita in a state and electoral votes per capita within that state - and thus many of the variables used to capture political objectives - may be due to construction (the reliance of both measures on state population) and not due to political designs (see Wallis, 1998, and references therein). That work informs the research presented here, both in testing the robustness of our findings and in avoiding empirical specifications in which results hold by construction. 
In empirical work on the more recent experience in the United States in the delivery of pork, Levitt and Snyder (1995) find that the percent voting Democratic in a congressional district is a significant determinant of overall federal assistance expenditures per congressional district in the U.S., when Democrats control the U.S. Congress and the Presidency. ${ }^{2}$ The findings of many empirical studies suggest that politics may be responsible for large efficiency losses (see Inman, 1988; Hird, 1991).

We will proceed as follows. In Section 2 we present the conditions that characterize social assistance allocations in a system in which parties attempt to maximize the number of seats they win, and contrast that with that which obtains when parties attempt to maximize the probability of winning a majority of seats. We introduce the Albanian case study in Section 3, and present evidence on the importance of political institutions for this case in Section 4. Section 5 concludes with a discussion of other models that can be evaluated using the results presented here, and with a word on the extent to which the transitional nature of the Albanian government tempers the conclusions that can be drawn.

\section{Political institutions, political equilibria and income redistribution}

The framework adopted in much of the pork-barrel politics literature discussed in Section 1 is relevant for the Albanian case. In Albania in the first half of the 1990s, there were two main political parties. The party that came to power in the first elections held in the country was the Democratic party (party D). The only major opposition party was the Socialist party (party S), which had roots in the regime that ran the country until 1990. Because of the Socialist party's association with the earlier regime, some citizens would experience a loss of utility, unrelated to consumption, if the Socialists took power. For other citizens, utility would be enhanced. The parties compete for seats in the parliament, and members of parliament are elected from small geographic regions, known as communes.

We lay out simple, testable implications for two hypotheses of political behavior, using the Snyder framework. ${ }^{3}$ Our predictions are consistent with those that would obtain in either a Lindbeck and Weibull or a Dixit and Londregan framework. We assume parties D and $\mathrm{S}$ compete for seats in $N=\{1, \ldots n\}$ communes. Party $\mathrm{S}$ promises people in commune $k$ an amount

\footnotetext{
${ }^{2}$ Levitt and Snyder find more evidence of party effects in spending programs when allocations are made according to formulas, rather than when agencies have greater discretion.

${ }^{3}$ In his general model, Snyder allows parties to spend varying amounts in aggregate, but discusses the fixed budget case (relevant here) as a special case.
} 
$y_{k}$ in social assistance, and party $\mathrm{D}$ promises $x_{k}$. In aggregate, the amounts promised by the parties cannot exceed the total social assistance budget, and must be non-negative. Parties deliver the social assistance promised, because they will run for reelection and will face the same voters repeatedly. Snyder posits that the probability that party $\mathrm{D}$ wins the parliamentary seat in commune $i$ is

$$
p_{i}=p\left(x_{i}, y_{i}\right)=\frac{a_{i} h\left(x_{i}\right)}{a_{i} h\left(x_{i}\right)+\left(1-a_{i}\right) h\left(y_{i}\right)},
$$

where $a_{i} \in(0,1)$ represents the extent that party $\mathrm{D}$ is favored ideologically by voters in commune $i$. The function $h$ is assumed to be twice continuously differentiable, with $h^{\prime}>0, h^{\prime \prime}<0, h(0)=0$, all $x \geq 0$.

\subsection{Parties allocating resources to maximize the number of seats won}

In order to obtain equilibrium allocations, we must know the objective function of the decision maker. We will contrast the allocations from two objective functions. In the first, the decision maker wishes to maximize the number of seats his or her party wins in the legislature. ${ }^{4}$ With this objective, in equilibrium parties never differ in the level of social assistance they promise to a given commune, and the legislative seat goes to the party that has what Snyder calls 'a natural advantage' in that commune (a higher value of $a$ ).

Social assistance to commune $i$ will be higher, the more competitive is the race in that commune. To see this, note that in order to maximize the number of seats won, parties allocate social assistance across communes in such a way as to equalize the marginal effects of assistance on the probability of winning each seat. Using Eq. (1), it is easy to show that for any given level of assistance, the marginal effect of assistance on the probability is higher when the partisan bias in favor of either party is lower. Thus, to maximize the effects of allocating funds on the number of seats won, more money is allocated to those communes where the probability of winning is close to one-half - that is, where partisan bias is low. These are the 'swing' communes. ${ }^{5}$

\footnotetext{
${ }^{4}$ In this framework, Snyder discusses conditions under which a pure strategy Nash equilibrium exists and is unique.

${ }^{5}$ See Snyder, Comment 3.1 (p. 642) for a succinct proof. Snyder notes that in this framework there are no corner equilibria (ones in which no money is allocated to some communes). These do not occur here because, if one party spends nothing on the race in a commune, then there is no solution to the other party's maximization problem: it would want to spend an amount arbitrarily close to zero, but not equal to zero. Lindbeck and Weibull rule out corner solutions by assuming that the marginal utility of assistance goes to infinity as the allocation goes to zero. In a similar fashion, zero assistance allocations are ruled out for parties maximizing the probability of winning a majority of seats.
} 
This is the basis of the empirical test for our first model. We will regress commune $k$ 's social assistance budget on the absolute distance of $p_{k}$ from 0.5 , holding constant the commune's initial endowment of resources. We will use the percent of the commune voting with the Democratic party in the 1994 referendum on the constitution as our measure of $p_{k}$.

\subsection{Parties allocating resources to maximize the probability of winning a majority of seats}

In Albania, having a majority vote in the Parliament may be an end in itself. As its most important function, the majority party in the Parliament chooses the president. If the president's goal is to maximize the probability of his own reelection, his objective may be to maximize the probability that his party wins a majority of seats in the legislature.

Both Snyder and Lindbeck/Weibull discuss such a case, under the assumptions that the probability of winning the seat in any given commune is independent across communes, and that one party is more popular than the other. ${ }^{6}$ More resources are again allocated to swing communes in this case, for the same reason that swing communes are favored by a party maximizing the number of seats it wins: at the same level of social assistance, the change in the probability of winning a seat will be higher, given an additional dollar of social assistance, the lower is the partisan bias in favor of the party.

However, the optimization problem here is more complex than one in which parties are simply trying to maximize the number of seats won. Both Snyder and Lindbeck/Weibull show that, in addition to favoring swing communes, the more popular party in this case will favor 'pivotal' communes, defined as those communes without whose support it is less likely to win a majority of seats. As Snyder notes 'Party [D] only cares about winning the election in district $i$ if the district is pivotal, that is, if winning or losing in district $i$ would make the difference between winning and losing a majority in the legislature. Obviously this occurs only if $[\mathrm{D}]$ wins exactly half of the other seats. Thus, the higher the probability that $[\mathrm{D}]$ wins exactly half of the other seats, the more it cares about winning in district $i$ (p. 648). When the more popular party [D] expects to win exactly half of the seats other than that from commune $i$, it must be that party $\mathrm{D}$ is more popular in commune $i$. (Otherwise, party $\mathrm{D}$ would not be more popular overall.) Pivotal communes, on whom more resources will be spent, come from the set of communes in which the popular party expects to receive more than $50 \%$ of the vote. ${ }^{7}$

\footnotetext{
${ }^{6}$ If the two parties were equally popular, only swing communes would be favored, even if each party's objective is to maximize the probability of winning a majority of seats.

${ }^{7}$ Snyder provides sufficient conditions under which a unique Nash equilibrium exists in this case.
} 
A testable implication of this observation is that when pairing two communes - one that favors party $\mathrm{D}$ to the same extent that another favors party $\mathrm{S}$ - the commune favoring the more popular party is more likely to be pivotal, and thus we would expect it to receive greater resources. ${ }^{8}$ In a regression framework, holding constant the absolute distance of $p_{k}$ from 0.5 , communes in which the Democratic party is more popular should receive a greater share of the social assistance budget, if the decision maker's objective is to maximize the probability of winning a majority of seats. Thus, for our test of this second model, we will regress commune $k$ 's social assistance budget on the distance of $p_{k}$ from 0.5 , capturing the 'swing' commune effect, and on $p_{k}$ itself, capturing the 'pivotal' commune effect. Nothing in the theory requires that the 'pivotal' effect on the allocation of resources be linear in $p_{k}$. We have added quadratic terms in $p_{k}$, but because coefficients on these terms were small and statistically insignificant we do not report results with quadratic terms in the tables below. We will again use the percent of the commune voting with the Democratic party in the 1994 referendum on the constitution as our measure of $p_{k}$.

Before turning to the empirical results in Section 4, we introduce our data and the germane features of the Albanian political system as it existed through the end of 1996 (the period for which we have data).

\section{Albanian political and economic institutions}

Albania is a parliamentary republic with executive, legislative, and judicial branches. The head of state is a president, elected by the parliament. (In the first round of balloting, a candidate must receive two-thirds of the votes to be elected. If no candidate succeeds in doing so, a runoff takes place between the two candidates who received the most votes on the first ballot. In the runoff election, a simple majority is needed to win.) The president nominates a prime minister and appoints and discharges the cabinet. The president can put forward legislation, and sign or veto legislation adopted by the legislature. The president held a great deal of power in Albania between 1992 and 1996. It is his reelection that the 'decision maker' discussed in Section 2 may be trying to assure. If the President makes decisions on block grants, we might expect to see block grants made to maximize the probability that the President wins the next election, rather than to maximize the size of the majority achieved.

There were two major political parties in Albania over the period we are investigating (1992-96). The Democratic party held a majority of seats in

\footnotetext{
${ }^{8}$ For discussion of this point, see Snyder, Proposition 4.3, p. 652.
} 
Parliament from 1992 until the end of 1996, and the president (Sali Berisha) was a Democrat. The main opposition party was the Socialist party, which grew out of the former Communist party.

\section{Social assistance}

Albania, then the poorest country in Europe, began its transition from Stalinist dictatorship to parliamentary republic in late 1990. To support the most vulnerable during the transition to a market economy, the central government set up a block grant program in the second half of 1993. In 1996, 145,000 families received assistance, with 65,000 receiving 'full' assistance and 80,000 families receiving 'partial' assistance, with exact payment dependent on the families' other sources of income. The 'full' payment is tied to the level of unemployment benefits, and was not to exceed $250 \%$ of the base level unemployment payment (amounting to roughly \$53).

Program funds are distributed through the Ministry of Labor, which defines the program's eligibility criteria and monitors its performance. Money in this program is nominally distributed to the communes as block grants. The commune petitions the Ministry of Labor on behalf of families that it determines are eligible to receive assistance, and divides the grant between those eligible once the grant has been delivered.

There are three steps in the funding process. First, families applying for assistance at the commune's Section of Social Assistance must prove that they meet the Ministry of Labor's criteria for eligibility. They must have in hand certificates documenting their land holdings, their tax payments, their employment status, their automobile ownership, and their pension receipt. The amount of money a family is eligible to receive is based on income, including transfers from the government and remittances from family members abroad, and upon potential income from land and animal husbandry. If a family meets the eligibility requirement for social assistance, the program's administrator adds the family's name to the list of potential recipients. In the next step, the social administrator presents the list to the commune council, which is free to add names to - and strike names from - the list. This may be done, for example, if the council believes some households of equal or greater need than those currently on the list have been overlooked. This list is then sent to the Ministry of Labor where a decision is made over the size of the grant to be given to the commune. The Ministry has little control over the household list, but does determine the size of the commune's award. In practice, then, this program is a hybrid, with some features of a block grant and some of a centrally mandated - locally administered program. 


\section{Data}

Our data come from three sources. The Ministry of Labor provided data on the receipt of social assistance funds for all communes in the country, together with information on commune population and land holdings. The country is divided into 36 districts, which are in turn divided into 315 (rural) communes and 45 (urban) municipalities. Communes were constructed to contain at least 5000 people, and represent 10 villages on average. Our data come from communes (rural areas) only; data in the community survey were only collected in the rural communes.

There is significant dispersion both in the size of communes, and in the number of families receiving assistance. The dispersion in families treated is mirrored in the total size of the block grant by commune, presented in the left panel of Fig. 2. However, population is not the only factor determining the size of the block grant. The right panel of Fig. 2 presents the dispersion in the average amount of social assistance per family in October 1995, by commune. The median commune receipt per family is roughly 1200 lek per month but, as is apparent in Fig. 2, there is a long upper tail, with one commune (Luz I Vogel) receiving 4000 lek per family. Some of this dispersion is due to differences in the size of family land holdings between communes and communes where households have larger land holdings should receive lower levels of assistance - and some to differences in commune receipt of other government funds, such as unemployment insurance and pensions. As we will see below, some of the difference appears to be due to political affiliation.

The Socialist party in Albania provided data on voting records in the 1992 vote for local government and the 1994 referendum on the constitution (favored by the Democratic party). These two measures represent two independent readings of ideological bias in favor of the Democratic party. The local elections in 1992 were used to elect local commune councils for the first time. The election was held a year before the social assistance program was put in place. The
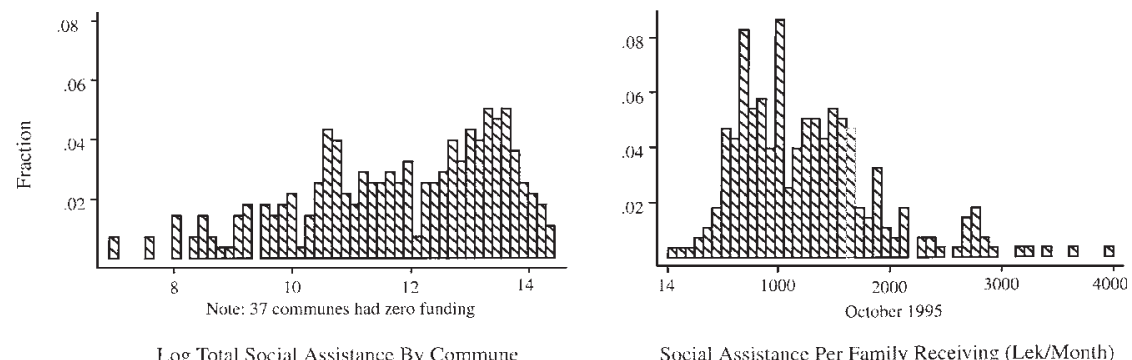

Social Assistance Per Family Receiving (Lek/Month)

Fig. 2. Social assistance by commune. 
referendum on the constitution did not elect any candidates to office, and provides a second measure of the underlying sentiment toward the Democratic party. These two measures are highly correlated (0.73). These voting data were collected at the district level, not at the commune level, but match closely data we have at the commune level for a subset of communes. We will use these district-level data when analyzing the full set of communes in the country.

Our third data set comes from a survey we ran in 49 communes in the Fall of 1996, which we will refer to as the 'Community Survey'. We asked the commune mayor questions about commune voting patterns, and asked the commune's social assistance administrator questions about the block grant program. The match between the district level voting data (Socialist party data) for these communes and the commune level data (Community Survey data) show a strong, positive correlation between these two measures of party bias. The commune administrators and the Ministry of Labor also agree on the total social assistance budget reported for August 1996.

We combine the district-level political data with the Ministry of Labor data to obtain one set of estimates on the relationship between politics and block grants. We then compare these results with those obtained from the commune-level voting data and block grant data obtained from the Community Survey.

\section{Political influence in Albanian block grants}

Without additional assumptions, theory does not provide exact functional forms with which to test political objectives. Table 1 presents results using several specifications for the size of the block grant. The first two columns of Table 1 present the results of regressing the commune's total block grant in August 1996 on the two measures of political alignment discussed in Section 3. These are a measure of the extent to which the commune is 'pivotal' for the Democratic party (here the percent of the commune voting with the Democratic party in the constitutional referendum of 1994), and the extent to which the commune is a 'swing' commune (the absolute difference between the commune vote and $50 \%$ ).

In all specifications, the extent to which a commune is pivotal has a positive effect on the size of the block grant received, while distance from being a swing commune has a negative effect on the size of grant received. The magnitude of the effect is large. A one standard deviation increase in the percent of the commune voting for the referendum (12.94), holding constant the commune population, the number of families for whom aid is requested, and commune land holding patterns, is predicted to increase a commune's social assistance by 40,000 lek. This is roughly a third of the median block grant $(123,000$ lek), and represents $13 \%$ of the mean grant received $(319,000$ lek). The low $t$-statistics on the political variables separately in many specifications is due to the high degree 
Table 1

The impact of the 1994 referendum vote on funds awarded to communes in August 1996

\begin{tabular}{|c|c|c|c|c|c|c|}
\hline & Total fund & s (1000s) & Log total $\mathrm{fu}$ & ands & Funds/ & Fund/ \\
\hline Percent district vote for & 2.86 & 3.12 & 0.015 & 0.01 & 0.013 & 0.0008 \\
\hline & & & 4 & & & \\
\hline referendum 1994 & (1.3) & $(1.2)$ & (7.4) & $(4.7)$ & $(3.2)$ & (1.6) \\
\hline Abs value (pct for ref -50 ) & $\begin{array}{r}-3.72 \\
(1.3)\end{array}$ & $\begin{array}{r}-3.72 \\
(1.1)\end{array}$ & $\begin{array}{r}-0.09 \\
(2.1)\end{array}$ & $\begin{array}{c}-0.006 \\
(1.3)\end{array}$ & $\begin{array}{c}-0.019 \\
(2.2)\end{array}$ & $\begin{array}{c}-0.0005 \\
(0.7)\end{array}$ \\
\hline $\begin{array}{l}F \text {-test: political variables } \\
(p \text {-value })\end{array}$ & $\begin{array}{l}6.27 \\
(0.0048)\end{array}$ & $\begin{array}{l}6.23 \\
(0.0050)\end{array}$ & $\begin{array}{l}33.86 \\
(0.0000)\end{array}$ & $\begin{array}{l}18.21 \\
(0.0000)\end{array}$ & $\begin{array}{l}14.36 \\
(0.0000)\end{array}$ & $\begin{array}{l}5.23 \\
(0.0104)\end{array}$ \\
\hline $\begin{array}{l}\text { Total families in commune } \\
\text { requesting assistance }\end{array}$ & $\begin{array}{r}1.00 \\
(4.8)\end{array}$ & $\begin{array}{l}0.968 \\
(50.0)\end{array}$ & - & - & $\begin{array}{c}-0.002 \\
(1.5)\end{array}$ & $\begin{array}{l}0.0001 \\
(4.6)\end{array}$ \\
\hline $\begin{array}{l}\text { Log (total families) in commune } \\
\text { requesting assistance }\end{array}$ & - & - & $\begin{array}{l}0.874 \\
(15.5)\end{array}$ & $\begin{array}{l}0.864 \\
(13.9)\end{array}$ & - & - \\
\hline $\begin{array}{l}\text { Commune population (100s) } \\
\text { January } 1993\end{array}$ & - & $\begin{array}{c}30.04 \\
(3.2)\end{array}$ & - & - & - & $\begin{array}{c}-0.0004 \\
(3.3)\end{array}$ \\
\hline $\begin{array}{l}\text { Log (commune population) } \\
\text { January } 1993\end{array}$ & - & - & - & $\begin{array}{l}0.511 \\
(2.2)\end{array}$ & - & - \\
\hline $\begin{array}{l}\text { Families without land due } \\
\text { to state control of land }\end{array}$ & $\begin{array}{l}8613 \\
\quad(3.7)\end{array}$ & $\begin{array}{l}4816 \\
\quad(1.1)\end{array}$ & $\begin{array}{l}32.8 \\
(3.8)\end{array}$ & $\begin{array}{l}25.4 \\
(2.3)\end{array}$ & $\begin{array}{c}30.4 \\
(1.4)\end{array}$ & $\begin{array}{l}1.70 \\
(3.0)\end{array}$ \\
\hline Families holding less than & 1447 & 364 & 2.18 & -0.552 & 3.82 & 0.224 \\
\hline $500 \mathrm{~m}^{2}$ of land per member & $(1.2)$ & $(0.3)$ & (1.6) & $(0.3)$ & $(1.0)$ & (1.4) \\
\hline $\begin{array}{l}\text { Families holding } \\
500-1000 \mathrm{~m}^{2} \text { of land } \\
\text { per member }\end{array}$ & $\begin{array}{l}3.02 \\
(0.2)\end{array}$ & $\begin{array}{r}-785 \\
(0.5)\end{array}$ & $\begin{array}{c}-0.325 \\
(0.1)\end{array}$ & $\begin{array}{r}-3.27 \\
(1.1)\end{array}$ & $\begin{array}{l}1.73 \\
(0.3)\end{array}$ & $\begin{array}{l}0.108 \\
(0.5)\end{array}$ \\
\hline $\begin{array}{l}\text { Families holding } \\
1000-1500 \mathrm{~m}^{2} \text { of land } \\
\text { per member }\end{array}$ & $\begin{array}{l}78.1 \\
(0.1)\end{array}$ & $\begin{array}{r}-877 \\
(1.3)\end{array}$ & $\begin{array}{l}1.71 \\
(1.2)\end{array}$ & $\begin{array}{r}-1.08 \\
(0.8)\end{array}$ & $\begin{array}{r}5.46 \\
(1.2)\end{array}$ & $\begin{array}{c}-0.057 \\
(0.5)\end{array}$ \\
\hline $\begin{array}{l}\text { Families holding } \\
1500-2000 \mathrm{~m}^{2} \text { of land } \\
\text { per member }\end{array}$ & $\begin{array}{r}-490 \\
(1.2)\end{array}$ & $\begin{array}{r}-1623 \\
(2.9)\end{array}$ & $\begin{array}{l}0.048 \\
(0.1)\end{array}$ & $\begin{array}{r}-2.86 \\
(2.0)\end{array}$ & $\begin{array}{r}-1.99 \\
(1.1)\end{array}$ & $\begin{array}{c}-0.093 \\
(1.4)\end{array}$ \\
\hline $\begin{array}{l}\text { Families holding } \\
2000-3000 \mathrm{~m}^{2} \text { of land } \\
\text { per member }\end{array}$ & $\begin{array}{l}201 \\
(1.1)\end{array}$ & $\begin{array}{r}-869 \\
(2.4)\end{array}$ & $\begin{array}{r}-1.00 \\
(0.9)\end{array}$ & $\begin{array}{r}-3.46 \\
(1.7)\end{array}$ & $\begin{array}{r}-2.33 \\
(0.9)\end{array}$ & $\begin{array}{l}0.024 \\
(0.6)\end{array}$ \\
\hline
\end{tabular}


Table 1 (Continued)

\begin{tabular}{lcccccc}
\hline & Total funds (1000s) & Log total funds & $\begin{array}{l}\text { Funds/ } \\
\text { fam } \\
\text { receiving }\end{array}$ & $\begin{array}{l}\text { Fund/ } \\
\text { capita }\end{array}$ \\
& & & & & & \\
\hline Families holding more than & -283 & -1323 & -1.06 & -3.79 & -1.65 & -0.080 \\
$3000 \mathrm{~m}^{2}$ of land per member & $(1.5)$ & $(3.4)$ & $(1.1)$ & $(1.8)$ & $(0.7)$ & $(1.5)$ \\
$F$-test: joint significance & 4.77 & 5.03 & 3.50 & 2.61 & 1.40 & 4.10 \\
land variables ( -value) & $(0.0008)$ & $(0.0005)$ & $(0.0064)$ & $(0.0294)$ & $(0.2395)$ & $(0.0023)$ \\
Number of observations & 191 & 189 & 177 & 176 & 177 & 189 \\
$R^{2}$ & 0.7444 & 0.7613 & 0.8908 & 0.8990 & 0.0450 & 0.6291 \\
\hline
\end{tabular}

${ }^{a} T$-statistics are reported in parentheses. Heteroskedasticity consistent standard errors are reported, allowing for clustering within districts. Variables on families owning land are divided by 10,000 (omitted category is landless families whose land was not taken by the government). A constant term is estimated but not reported.

of collinearity between the percent voting in favor of the Democratic party and the distance of that from $50 \%$. (This will be made clear in Table 2.) In all of these specifications, the extent to which a commune is pivotal and the extent to which it is a swing commune are jointly highly significant, which can be seen in row 3 , which presents $F$-tests of the joint significance of these variables.

These regressions are run for all communes for which we have information on commune land holding (191 communes). By the rules governing social assistance allocation, land holding should affect the size of the commune's social assistance allocation, and we find that commune land holding patterns influence the communes' social assistance much as the Ministry of Labor funding formula suggests they should (the omitted category here is the number of landless families whose land was not taken by the government). The results in all specifications suggest that the larger the number of families whose land was taken by the state, the larger the commune's block grant, holding all else equal. The larger the number of families with large farms, the smaller the commune's block grant. Families with very small land holdings have the same impact on the size of the block grant as landless families. Commune population has a positive and significant effect on the size of the total grant received (column 2), but does not change the size or significance of the political variables.

In columns 3 and 4, we regress the log of the total grant received on the log of the total number of families requesting assistance, and measures of commune party bias, with and without controls for the log commune population. The impact of the political variables is qualitatively and quantitatively similar to what was seen in columns 1 and 2. A one standard deviation increase in the percent of the commune's district voting with the Democrats is expected to increase social assistance funding by roughly $18 \%$, holding all else equal. 


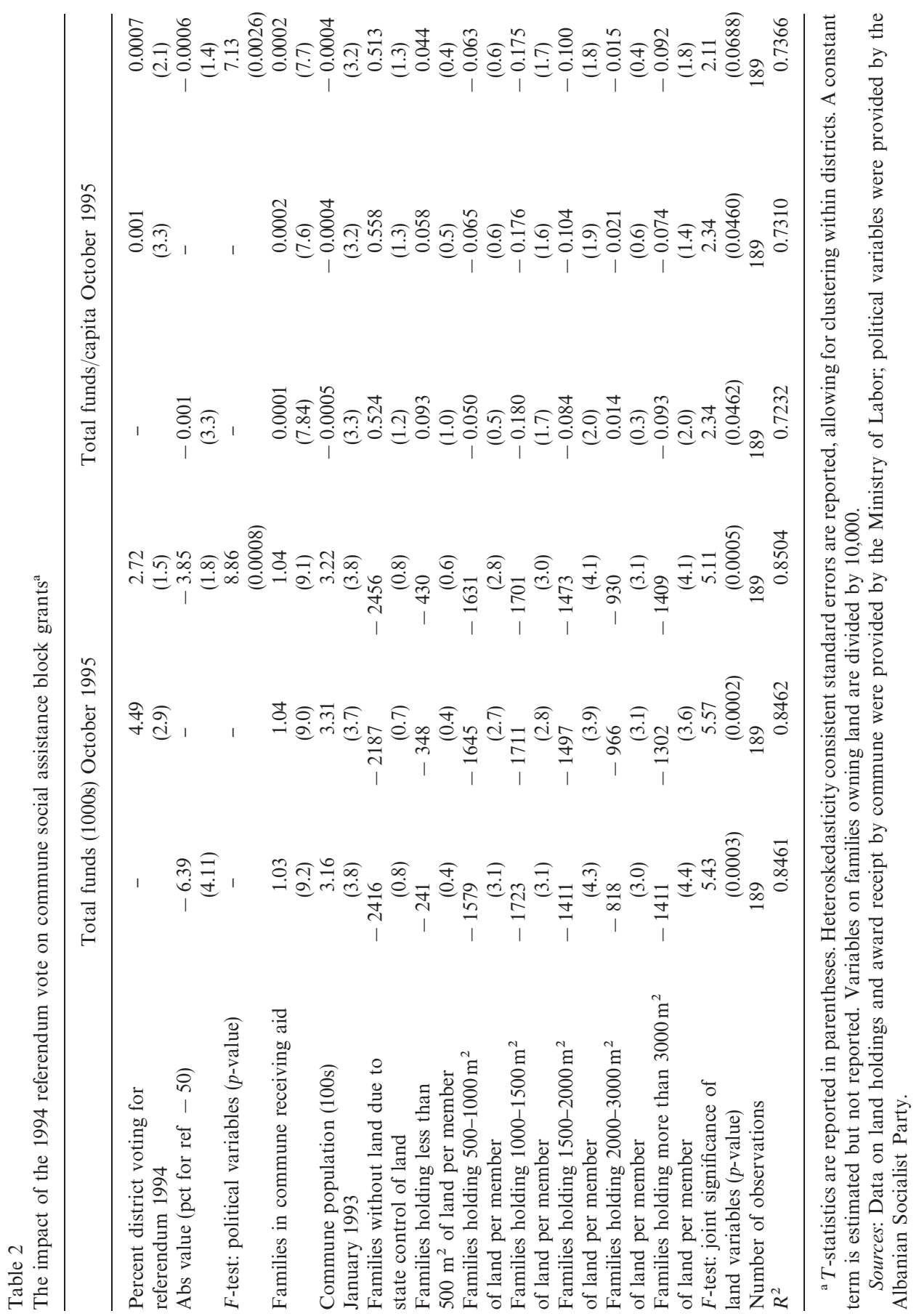


Columns 5 and 6 present alternative specifications. Column 5 looks at the determinants of block grant funds per family requesting assistance, and column 6 at funds per person in the commune. The same pattern emerges for the political variables coefficients, and the pattern and joint significance of these coefficients are robust to the inclusion/exclusion of commune population as a control.

Results in Table 1 suggest that the political bias of the commune may influence its block grant. The results are robust to functional form, and to the inclusion of controls for commune population. Results in Table 1 suggest that there is a 'kink' in the effect of the Democratic party popularity at the $50 \%$ mark. Because this will be of interest in discussion of alternative explanations in the next section, we tested the point at which such a 'kink' is most likely, given the data. Fig. 3 presents the $R^{2}$ s (representing a simple transformation of the likelihood) from regressions in which we allow our measure of a 'swing' commune to be the absolute difference between the commune's vote around a varying $x$ percent of the vote. The most likely kink point lies between 45 and $50 \%$ - very close to the $50 \%$ mark upon which the theory is predicated.

We explore these results further in Table 2, where results are presented for funding at a different point in time, October 1995 (results for 1995 are similar to both those for 1994 and 1996). We present results in columns 1-3 for the impact of the district's referendum vote on total funds received, and in columns 4-6 on funds received per capita. Table 2 makes clear that the impact of these political

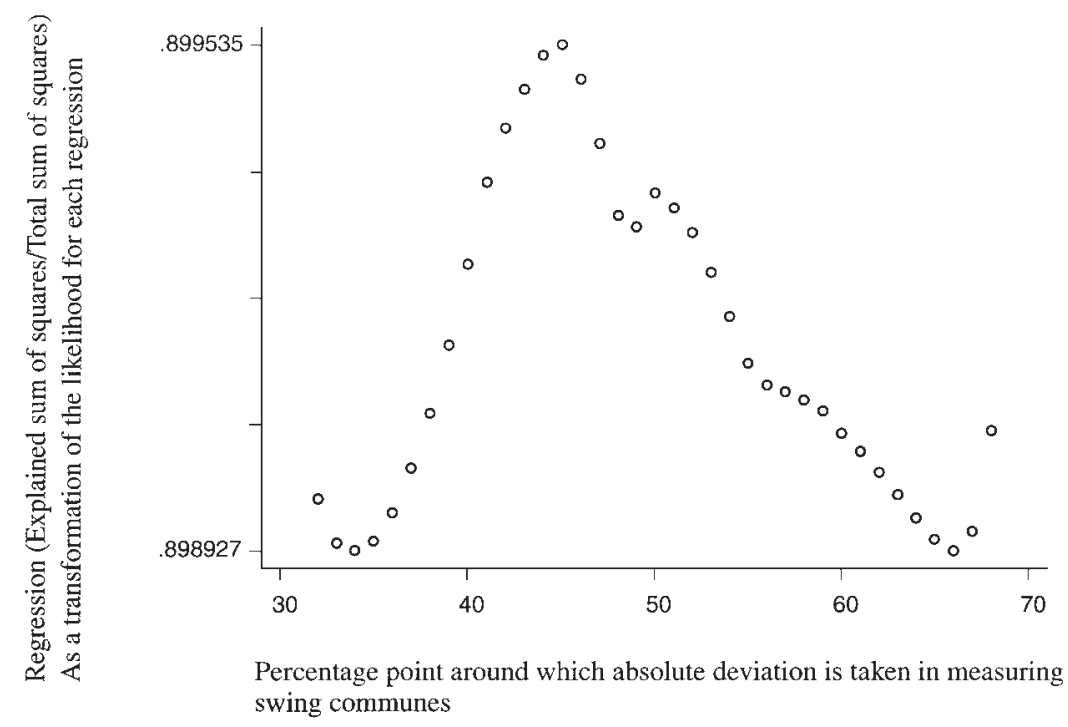

Fig. 3. Estimating the point around which communes are treated as swing communes. 
Table 3

Total social assistance funds awarded to communes ${ }^{\mathrm{a}}$, Community Survey data

\begin{tabular}{|c|c|c|c|c|c|c|}
\hline \multirow[b]{2}{*}{$\begin{array}{l}\text { Percent of commune voting } \\
\text { for referendum } 1994\end{array}$} & \multicolumn{3}{|c|}{$\begin{array}{l}\text { Log total social asst funds in month } \\
\text { prior to survey }\end{array}$} & \multicolumn{3}{|c|}{$\begin{array}{l}\text { With controls for land hold- } \\
\text { ing in the commune }\end{array}$} \\
\hline & $\begin{array}{l}0.015 \\
(2.6)\end{array}$ & - & $\begin{array}{l}0.013 \\
(2.3)\end{array}$ & $\begin{array}{l}0.016 \\
(1.9)\end{array}$ & - & $\begin{array}{l}0.009 \\
(0.9)\end{array}$ \\
\hline Abs value (pct for ref -50 ) & - & $\begin{array}{c}-0.020 \\
(2.5)\end{array}$ & $\begin{array}{c}-0.011 \\
(1.4)\end{array}$ & - & $\begin{array}{c}-0.026 \\
(2.1)\end{array}$ & $\begin{array}{c}-0.018 \\
(1.2)\end{array}$ \\
\hline $\begin{array}{l}F \text {-test: political variables } \\
(p \text {-value })\end{array}$ & - & - & $\begin{array}{l}3.63 \\
(0.0350)\end{array}$ & - & - & $\begin{array}{l}2.27 \\
(0.1288)\end{array}$ \\
\hline $\begin{array}{l}\text { Log (number of families) in } \\
\text { commune receiving aid }\end{array}$ & $\begin{array}{l}0.759 \\
(3.1)\end{array}$ & $\begin{array}{l}0.911 \\
(4.1)\end{array}$ & $\begin{array}{l}0.801 \\
(3.3)\end{array}$ & $\begin{array}{l}0.403 \\
(1.2)\end{array}$ & $\begin{array}{l}0.469 \\
(1.6)\end{array}$ & $\begin{array}{l}0.439 \\
(1.4)\end{array}$ \\
\hline Log (commune population) & 0.038 & -0.114 & -0.061 & 0.352 & 0.301 & 0.288 \\
\hline January 1993 & $(0.2)$ & $(0.5)$ & $(0.3)$ & $(1.4)$ & $(1.2)$ & $(1.1)$ \\
\hline Fraction of households & - & - & - & -0.704 & -0.747 & -0.683 \\
\hline holding over $500 \mathrm{~m}^{2} /$ member & - & - & - & $(1.9)$ & $(2.3)$ & $(1.9)$ \\
\hline Number of observations & 47 & 47 & 47 & 26 & 26 & 26 \\
\hline$R^{2}$ & 0.6592 & 0.6296 & 0.6708 & 0.7045 & 0.7140 & 0.7259 \\
\hline
\end{tabular}

${ }^{\text {a }}$ Robust $T$-statistics are reported in parentheses. A constant term is estimated but not reported.

Sources: Political variables and commune award levels were collected as part of the Community Survey, August-October 1996.

variables is not driven by their joint inclusion. Taken separately, distance from being a 'swing' commune (columns 1 and 4), on one hand, and partisan loyalty toward the Democratic party (columns 2 and 5), on the other, are each significant predictors of grant allocation.

Data collected locally through the Community Survey present the same picture. The analysis of these data begins in Table 3, where the log (total monthly social assistance budget) for the commune in the late summer or early Fall of 1996 is regressed against the percentage of the commune voting for the 1994 referendum, and against the absolute deviation of the commune's vote from $50 \%$, controlling for other information available about the commune. The coefficients on the political variables are of the same size as those reported from the first data set and are also significant. These, then, provide an independent check on the results presented in Tables 1 and 2 .

The last three columns of Table 3 present results that also control for the sizes of family land holdings within these communes. This information was available from the Ministry of Labor for only half of the communes in the Community Survey. Even with this small sample, the land holding variables have the same effect here that they had in the larger data set: the number of families with larger land holdings is negatively correlated with the size of the block grant. 


\section{Alternative explanations and conclusions}

The results presented in Fig. 1 and in Tables 1-3 suggest that there is a positive, significant, and robust relationship between bias in favor of the Democratic party and the size of the commune's block grant. However, this does not rule out the possibility that the correlation is due to some omitted variable that is driving both votes for the Democratic party and the size of the commune's block grant. For example, very poor communes may have voted with the Democratic party in 1994, perceiving it to be a vote for change, and may also receive the largest block grants because they are poor.

Our results in Tables 1-3 provide some evidence against this interpretation, in that they control for the observable measures of poverty that the Ministry of Labor would have used to determine the size of block grants - land holding variables and the number of households for whom aid has been requested. We attempt to control for unobservable commune characteristics that may drive both the commune's voting patterns and its grant receipts by looking at changes in funding over time. The social assistance program was most generous in 1994. The average commune block grant was close to 400,000 lek per month in October 1994. That number had fallen to roughly 300,000 lek per month by October 1995, because of strains on the national budget. Table 4 presents the determinants of changes in the commune's log social assistance from one year to the next. This allows us to control for any level differences in poverty between

Table 4

Change in commune's social assistance awards ${ }^{\mathrm{a}}$, log first differences

\begin{tabular}{|c|c|c|c|c|c|}
\hline \multirow[b]{2}{*}{$\begin{array}{l}\text { Percent of the commune voting } \\
\text { for the referendum on the } \\
\text { constitution } 1994 \\
\text { Abs value(pct for ref }-50 \text { ) }\end{array}$} & \multicolumn{5}{|c|}{ Community Survey data, Log funding 1996 - Log funding 1995} \\
\hline & - & $\begin{array}{l}0.008 \\
(1.8)\end{array}$ & - & $\begin{array}{l}0.010 \\
(2.4)\end{array}$ & $\begin{array}{l}0.008 \\
(1.7)\end{array}$ \\
\hline Abs value(pct for ref -50 ) & - & - & $\begin{array}{l}0.008 \\
(1.1)\end{array}$ & $\begin{array}{l}0.013 \\
(1.8)\end{array}$ & $\begin{array}{l}0.005 \\
(0.7)\end{array}$ \\
\hline $\begin{array}{l}\text { Log (families) in commune } \\
\text { requesting aid }\end{array}$ & $\begin{array}{c}-0.025 \\
(0.2)\end{array}$ & $\begin{array}{c}-0.069 \\
(0.6)\end{array}$ & $\begin{array}{c}-0.049 \\
(0.5)\end{array}$ & $\begin{array}{c}-0.122 \\
(1.1)\end{array}$ & $\begin{array}{c}-0.043 \\
(0.4)\end{array}$ \\
\hline $\begin{array}{l}\text { Log commune population } \\
(10,000 \text { s) Jan } 1993\end{array}$ & $\begin{array}{l}0.199 \\
(1.1)\end{array}$ & $\begin{array}{l}0.188 \\
(1.1)\end{array}$ & $\begin{array}{l}0.259 \\
(1.4)\end{array}$ & $\begin{array}{l}0.286 \\
(1.7)\end{array}$ & $\begin{array}{l}0.058 \\
(0.3)\end{array}$ \\
\hline $\begin{array}{l}\text { Fraction of families holding } \\
\text { more than } 500 \mathrm{~m}^{2} \text { of land } \\
\text { per family member }\end{array}$ & - & - & - & - & $\begin{array}{l}0.084 \\
(0.5)\end{array}$ \\
\hline Number of observations & 44 & 44 & 44 & 44 & 22 \\
\hline$R^{2}$ & 0.0371 & 0.1127 & 0.0639 & 0.1802 & 0.1726 \\
\hline
\end{tabular}

${ }^{\text {a }} T$-statistics are reported in parentheses. A constant term is estimated but not reported. Source: Community Survey 1996. 
the communes that may have given way to differences in funding. We find that the commune's bias in favor of the Democratic party affects not only the level differences in funding, but also the change in funding over time. In results presented in Tables 1-3, we cannot rule out that poverty was an omitted variable leading to correlation between the commune's vote for the referendum in 1994 and its funding levels in 1994, 1995 and 1996. However, it seems unlikely that voting for the referendum in 1994 would be correlated with the change in poverty in the communes between 1995 and 1996. This adds additional evidence that the size of the block grant depends upon the commune's political leanings. ${ }^{9}$

The results presented here also rule out a simple alternative hypothesis on resource allocation. Besley and Coate (1997) provide a model of representative democracy in which voters vote their preferences and candidates, once elected, carry out their most preferred policies. In the Albanian case, this would suggest communes vote for candidates who are like them, and are rewarded with social assistance after the election. This could explain the positive relationship between bias in favor of the Democratic party and increased social assistance funding, but does not explain the 'kink' in funding around the 50\% mark.

Results here suggest a fundamental tension in block grant programs. Flexibility in spending money at the local level, the heart of a block grant system, may come at a price. There is greater potential in such a system for the center to allocate funds on a basis other than economic need. This potential arises because block grants programs, by their nature, are not based on fixed funding rules. There has been a call in the United States to return to state governments many social programs currently funded and administered at the federal level. It seems likely that some of the political pressures at work in the Albanian system could also play a role in the U.S. and in other countries.

It is also true that the Albanian case study presented here was carried out on a new government and, for the Albanians, a new system of government. New research on the politics of countries in transition suggests that, while a country is in transition, voters are likely to vote for parties according to their partisan alignment, rather than as a referendum on the competency of the current incumbent. Tucker (1999) presents evidence from 14 elections in five postcommunist countries that suggests knowledge of party type (party of the old regime versus reform party) is more important than knowledge of which party is currently in office, in predicting the effect of economic conditions on election outcomes. As countries complete the transition to market economies, party type is expected to give way to incumbent performance as the key to understanding the interaction between economic performance and electoral outcomes. If this is

\footnotetext{
${ }^{9}$ We cannot explain why the coefficient on the 'swing' variable (distance to $50 \%$ of the vote) is positive. This may be an interesting avenue to explore in future work. However, as is clear from Table 4, its size and significance are not robust to specification.
} 
the case, over time a party's 'natural advantage' in any given commune in Albania may come to reflect the economic performance of that commune when the party is in office, instead of the commune's ties to the old regime.

\section{Acknowledgements}

I thank Harold Alderman, Timothy Besley, Angus Deaton, Steve Levitt, Robert Inman, seminar participants at Columbia, Princeton, the University of Illinois, the University of Oregon, and the University of Pennsylvania, two anonymous referees and the editor for helpful comments.

\section{References}

Besley, T., Coate, S., 1997. An economic model of representative democracy. Quarterly Journal of Economics 112, 85-114.

Cox, G.W., McCubbins, M.D., 1986. Electoral politics as a redistributive game. The Journal of Politics 48, 370-389.

Dixit, A., Londregan, J., 1995. Redistributive politics and economic efficiency. American Political Science Review 89, 856-866.

Dixit, A., Londregan, J., 1996. The determinants of success of special interests in redistributive politics. Journal of Politics 58, 1132-1155.

Dixit, A., Londregan, J., 1998. Ideology, tactics, and efficiency in redistributive politics. Quarterly Journal of Economics 113, 497-529.

Hird, J.A., 1991. The political economy of pork: Project selection at the U.S. Army Corps of Engineers. American Political Science Review 85, 429-456.

Inman, R.P., 1988. Federal assistance and local services in the United States: The evolution of a new federalist fiscal order. In: Rosen, H.S. (Ed.), Fiscal Federalism: Quantitative Studies. University of Chicago Press, Chicago.

Levitt, S.D., Snyder, J.M., 1995. Political parties and the distribution of federal outlays. American Journal of Political Science 39, 958-980.

Lindbeck, A., Weibull, J.W., 1987. Balanced-budget redistribution as the outcome of political competition. Public Choice 52, 273-297.

Litvack, J., Ahmad, J., Bird, R., 1998. Rethinking Decentralization in Developing Countries. The World Bank Sector Studies Series, Washington, DC.

McLure, C.E., 1995. Comment on 'The dangers of decentralization' by Prud'homme. The World Bank Research Observer 10, 221-226.

Prud'homme, R., 1995. The dangers of decentralization. The World Bank Research Observer 10, 201-220.

Snyder, J.M., 1989. Election goals and the allocation of campaign resources. Econometrica 57, 637-660.

Tucker, J.A., 1999. Reconsidering economic voting: Party type versus incumbency in transition countries. Mimeo., Harvard University, Cambridge, MA.

Wallis, J.J., 1998. The political economy of New Deal spending revisited, again: With and without Nevada. Explorations in Economic History 35, 140-170. 